\title{
Методи лікування хворих із хронічними рановими дефектами нижніх кінцівок різного генезу
}

\author{
О.В. Пиптюк, С.Б. Телемуха, О.І. Дуб, Л.Б. Телемуха
}

Івано-Франківський національний медичний університет, кафедра хірургї̈ стоматологічного факультету, Івано-Франківськ

\section{Реферат}

Обстежено та проліковано 233 хворих із трофічними виразками нижніх кінцівок (ХTВ): 137 хворих із венозними (C6, Ep/Es, Pr 2, 3, 4, 18), 96 на хронічну критичну ішемію нижніх кінцівок III ст. (КІНК), зумовлену периферичною формою атеросклерозу судин. У першу і другу групу контролю ввійшли хворі, яким проведене комплексне лікування за загальноприйнятими схемами. У третю і четверту групу ввійшли хворі, яким використано ізольовану автодермопластику вільними перфорованими клаптями шкіри (АВПКШ). У п'ятій групі з венозними ХТВ виконано радикальний венекзерез. У шостій групі проведена катетеризація нижньої надчеревної артерії (КННА) з наступною доартеріальною інфузією медикаментозних середників, остеоперфорація великогомілкової кістки (ОПВГК).

Ключові слова: хронічні трофічні виразки нижніх кінцівок, хронічна венозна недостатність, облітеруючий атеросклероз, критична ішемія нижніх кінцівок, катетеризація нижньої надчеревної артерії, остеоперфорація великогомілкової кістки.

Methods of treatment of patients with chronic wounds defects of the lower extremities of different genesis A.V. Pyptiuk, S.B. Telemukha, O.I. Dub, L.B. Telemukha

Ivano-Frankivsk National Medical University, Department of Surgery Faculty of Dentistry, Ivano-Frankivsk

Abstract

Examined and treated 233 patients with trophic ulcers of lower extremities (HTU), of which 137 patients with venous (C6, Ep/Es, Pr 2, 3, 4, 18), 96 patients with peripheral form of atherosclerosis and chronic critical ischemia of lower extremities (KILE) III st. In the first and second control group included patients, who held conservative treatment by conventional schemes. In the third and forth group included patients who used isolated autodermoplastyk free perforated skin patches (AFPSP). In the fifth group of venous HTU made a radical venectomy. In the sixth group performed catheterization of inferior epigastric artery (KILE) followed by infusion of medication mullion, tibia osteoperforation.

Key words: chronic trophic ulcers of lower extremities, chronic venous insufficiency, arteriosclerosis, critical ischemia of lower extremities, epigastric artery catheterization, tibia osteoperforation.

Вступ. За статистичними даними, ХТВ призводять до інвалідності й непрацездатності частіше, ніж туберкульоз, ревматизм і транспортний травматизм разом взяті. Хворі „вимушені більше служити своїм ногам, ніж ноги їм”.

На облітеруючі захворювання судин кінцівок страждають $5 \%$ осіб середнього та похилого віку, що становить 3-4 \% всіх хірургічних захворювань. Частота оклюзійних захворювань артерій нижніх кінцівок у старшій віковій групі може сягати $23 \%$, серед яких у $20-40 \%$ розвивається ХКІНК [1].

Із кожним роком захворювання артерій нижніх кінцівок в Україні зростають і вже зареєстровано понад 2,5 млн. хворих. Близько половини всіх високих ампутацій пов'язані 3 ускладненнями периферичної форми атеросклерозу на фоні цукрового діабету, з них у 80-90 \% хворих передують хронічні виразкові дефекти [2,3].

Лікування венозних трофічних виразок нижніх кінцівок - актуальна проблема сучасної хірургії. На хронічну венозну недостатність нижніх кінцівок страждає 25-30\% жінок і 10-20 \% чоловіків. Як найважчий прояв хронічної венозної недостатності, трофічні виразки трапляються у 2 \% дорос- лого населення. У 0,3 \% виразки роками не загоюються і часто рецидивують.

Мета дослідження: вивчити безпосередні i віддалені результати лікування хворих із хронічними трофічними виразками різного генезу.

Матеріали та методи. За період з 2003 по 2018 роки обстежено та проліковано 233 хворих 3 XTB, із венозними (C6, Ep/Es, Pr 2, 3, 4, 18), 96 на хронічну критичну ішемію нижніх кінцівок III ст. (КІНК), зумовлену периферичною формою атеросклерозу судин. Жінок було 111 , чоловіків - 122. При загальноклінічних обстеженнях у хворих були виявлені супутні захворювання, серед яких у 73 \% діагностовано захворювання серцево-судинної системи; у $11,7 \%$ хронічні захворювання легень; у 9,3 \% - наслідки перенесеного гострого порушення мозкового кровообігу; у 4,7 \% - гострі та хронічні захворювання нирок; у $21 \%$ - інші хвороби. Це свідчить про підвищений операційний ризик оперованих пацієнтів. У 59 хворих виявлено по 2 супутні захворювання. Інші пацієнти мали 3 i більше супутніх захворювань. Середній вік хворих складав $58,5+12,5$ року $(\mathrm{m}=1,27), 71 \%$ хворих це особи працездатного віку до 60 років. 
Критерієм включення в дослідження були хворі з трофічними виразками, тривалістю патології не менше 6 тижнів. Сучасний підхід до консервативної терапії ТВ визначає необхідність комплексного лікування 3 урахуванням етіології і патогенезу розвитку трофічних розладів. У генезі ТВ у 96 (41,2 \%) хворих була периферична форма облітеруючого атеросклерозу і КІНК, у 137 (58,8 \%) - ПТФС і варикозна хвороба.

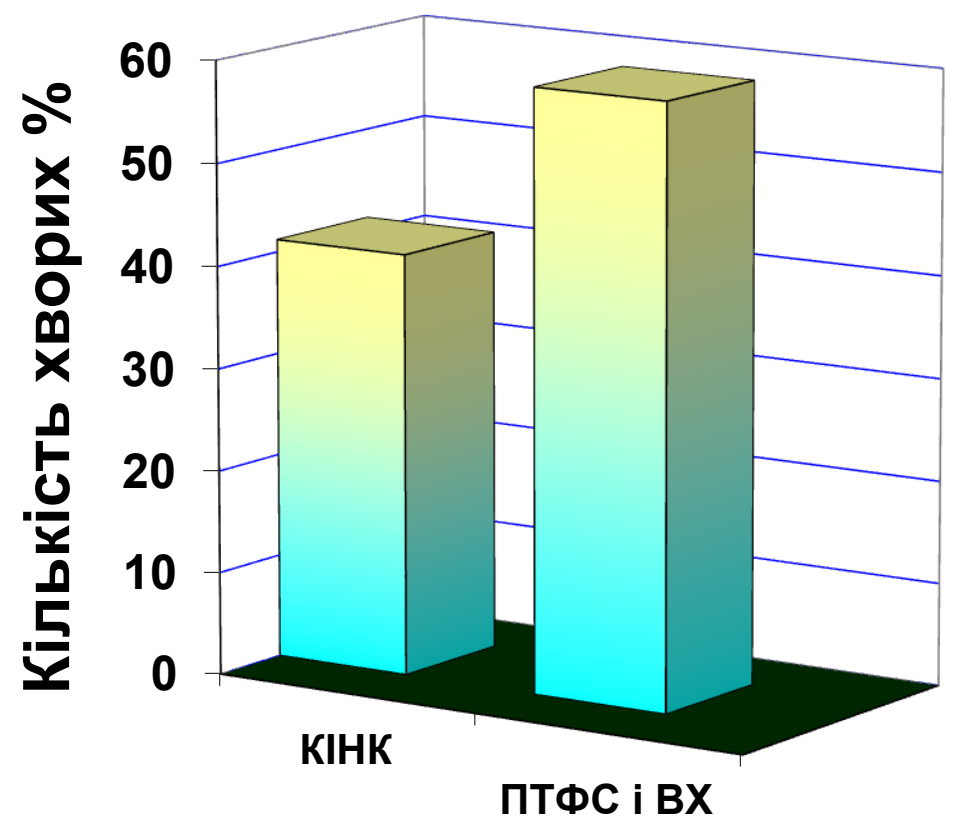

Рис. 1. Відсоток ХКІНК, ВХ і ПТФС в генезі в ХТВ нижніх кінцівок.

Результати досліджень та їх обговорення. Усі проліковані хворі комплексно обстежені.

Методи обстеження: Клінічне обстеження хворих; дуплексне кольорове сканування нижніх кінцівок; планіметричний i цитологічний методи; визначення мікробної картини виразки; транскутанна черезстегнова пункційна артеріографія за Сельдінгером.

Постійно вимірювали площу виразки при госпіталізіції і під час лікування. Використовували формулу (найбільші довжина х ширину х $n / 4$ ) або вимірювали за допомогою плівки, яка прилягає до пов'язки (Lohmann Rausher). Розмір ХTВ вимірювали з регулярним інтервалом у часі для контролю регенераторних процесів. Зменшення площі виразки у відсотках вираховували за формулою: $\mathrm{S}=\left(\mathrm{S}-\mathrm{S}_{0}\right) \times 100 / \mathrm{SxT}$, де $\mathrm{S}$ - площа рани при попередньому вимірі, $\mathrm{S}_{0}$ - площа рани в даний час, Т - кількість днів між вимірами. Отримані результати враховували при підготовці хворих із трофічними виразками до операції.

Ультразвукове дуплексне кольорове сканування проведено всім 233 пацієнтам. При кольоровому дуплексному скануванні визначали швидкість і об’єм кровотоку, оцінювали стан артеріальної і венозної стінки, просвіт судини.

У 96 пацієнтів кісточково-плечовий індекс (КПІ) становив менше 0,8, що вказувало про наявність артеріальної патології. Для кінцевого встановлення ступеня порушення кровопостачання, хворим про- водили кольорове дуплексне сканування артерій із кольоровим картуванням і рентген контрастну ангіографію. Рентгенконтрастну черезстегнову пункційну артеріографію проводили за Сельдінгером. Результати обстеження вказували на прохідність стегнової, підколінної артерії і «обрив» проходження контрастної речовини на гомілці.

За даними проведеного дослідження, горизонтальні патологічні венозні рефлюкси спостерігалися у 137 хворих із венозною пратологією. Кількість неспроможних пронизних вен коливалася від 4 до 20. Візуалізація пронизних вен під виразкою вдавалася рідко.

Мікробіологічне дослідження виразок проведено у 63 хворих. Мікробіологічна характеристика ран у досліджуваних хворих мала такий вигляд: Proteus vulgaris - у 12,5\% випадків, Ps. aeruginosae - в 50\% випадках, E. coli - в 6,2\% випадків, St. aureus - в $31,3 \%$ випадків, в $25 \%$ випадків ідентифіковані мікробні асоціації. Середній показник кількості колонісутворюючих одиниць до санації трофічних виразок склав $\lg =6,63 \pm 0,18$ на 1 г тканини; після санації $-\lg =4,80 \pm 0,09$ ( $<<0,001)$. Критерієм «чистоти хронічної рани» і готовності до автодермопластики був рівень мікробного обсіменіння не більше $5 \times 10^{5}$ на 1 г тканини. Результати антибіотикограм вказували на чутливість збудників до фторхінолонів I-IV поколінь і цефалоспоринів III-IV поколінь. У $14,5 \%$ пацієнтів була відсутня чутливість мікрофлори до антибіотиків. 
Проводили антибіотикотерапію у терапевтичних дозах, яку комбінували з протигрибковими препаратами (флуконазол, кетоконазол - 1 раз на 3-7 діб).

120 хворим провели цитологічне дослідження дна і країв виразки. Згідно з даними цитологічного дослідження, перебіг ХТВ нижніх кінцівок можна поділити на два періоди. Перший - до використання лікування - відповідає фазі ексудації i запалення. В мазку переважають нейтрофільні лейкоцити до 20-30 в полі зору, некробіоз (каріопікноз, каріорексис, каріолізис). Фагоцитоз майже відсутній або проявляється по типу незавершеного. Другий період - після і під час лікування - відповідає фазі регенерації i гранулювання. При цитологічному дослідженні простежується різке зменшення кількості мікроорганізмів. Фагоцитоз енергійний i завершений. Некробіотичні зміни в клітинах протікають помірно. В мазках, крім нейтрофілів, визначаються фібробласти, лімфоцити, моноцити, епітеліальні клітини.

Лікування гнійно-виразкових ускладнень ми розділили на три складові. У хворих на ХКІНК I етап включав відновлення або поліпшення реваскуляризації. II етап включав закриття дефекту тканин після некректомії і відновлення функції кінцівки. При відсутності позитивної динаміки лікування - висока ампутація на рівні середньої третини стегна [6].

У хворих із виразками венозного генезу на першому етапі проведено санацію виразки 3 наступним закриттям ранового дефекту. Другим етапом було проведено коригуючі оперативні втручання на венозній системі з ліквідацією рефлюксів.

Місцеве лікування включало:

• контроль за інфекцією виразки (Ст. 1А) [7];

- контроль ішемії. Ступінь 2B;

- очищення рани. Ступінь 2С;

- ранові перев’язки. Ступінь 2В

Згідно з рекомендаціями Європейської асоціації з управління ранами (ЕWMА), при догляді за ранами у хворих на СДС, ми притримувалися принципу радикального та повторного дебриденту (в основному хірургічному, аутолітичному, гідрохірургічному), частому огляді, бактеріальному контролі та ретельному балансі вологи $[8,9]$.

Нові види терапії за допомогою рекомбінантних технологій та пристроїв на базі клітинних технологій приносять користь і збільшують зцілення у вибраних пацієнтів або важких ран. 3 вказаною ціллю нами було запропновано трансплантацію культивованих фібробластів [10, 11].

Усі хворі розділені на такі групи:

1. Перша група (27) - хворі, яким проведено консервативне лікування венозних ХТВ традиційними методами. 2. Хворі (15), яким проведено консервативне лікування ішемічних ХТВ традиційними методами. 3. Хворі (20), яким з венозни- ми ХТВ проведена ізольована АВПКШ. 4. Хворі (15), яким з ішемічними ХТВ проведена ізольована автодермопластика без ОПВГК і АВПКШ. 5. Хворі (90) з венозними ХТВ, з них 39 радикально прооперовані без виконання автодермопластики, 51 радикально прооперовані з виконанням автодермопластики. 6. Хворі (66), в яких з КІНК використано поєднання з КННА (з інфузією медикаментозних середників для покращення реологічних $\mathrm{i}$ метаболічних процесів у кінцівці), ОПВГК. У 44 хворих шостої групи проведено некректомію або малу ампутацію на стопі, 3 них у 34 наступну АВПКШ.

Отже, перша, третя і п'ята групи - це хворі 3 венозною, а друга, четверта і шоста групи - 3 артеріальною патологією.

У групу першу і другу контролю ввійшли хвоpi, яким проведене консервативне лікування загальноприйнятими медичними середниками (непрямі антикоагулянти, дезагреганти, простагландини, антибіотики при наявності трофічних змін згідно 3 чутливістю після проведеного посіву). Як правило, ці хворі відмовлялися від оперативного лікування.

У п’ятій групі з венозними ХТВ проведено радикальний венекзерез, з метою усунення патогенетичних причин розвитку венозних ХТВ.

У шостій групі проведена катетеризація нижньої надчеревної артерії (КННА), остеоперфорація верхньої і середньої третини великогомілкової кістки (ОПВГК) ураженої кінцівки в кількості 5-6 перфораційних отворів на фоні довготривалої внутрішньоартеріальної інфузії антибіотиків і медикаментозних препаратів із наступною санацією гнійнонекротичного вогнища. У 44 хворих основної групи проведено некректомію або малу ампутацію на стопі, з них у 34 наступну АВПКШ. Термін функціонування доартеріального катетера становив від 3 до 28 діб, в середньому 14,1+0,88 доби.

Системна фармакотерапія. Тромбоцитарні дезагреганти: пентоксифілін - по 800 мг на добу довенно, ацетилсаліцилова кислота - 80 мг на добу, клопідогрель - по 75 мг 1 раз на добу, низькомолекулярні декстрани довенно 200-400 мл на добу, депротеїнізованого гемодеривату із крові телят у вигляді Актовегіну концентрату 4-5 мл на добу довенно і дом'язово 10-12 діб, простогландини Е1 два рази на добу не менше 10 діб. Хворі шостої групи вказані середники отримували доартеріально. У хворих із венозною патологією обов'язково призначали венотоніки.

Згідно з TASC (2000р.), оцінку результатів лікування проводили за стандартизованими часовими інтервалами, рекомендованими міжнародними судинними і серцево-судинними хірургами: безпосередні результати - впродовж 30 діб, короткострокові результати - від 1 до 6 місяців по операції, проміжні результати - від 12 до 24 місяці по операції, віддалені результати - від 2-х років після операції.

Критерії оцінки безпосередніх результатів лікування хворих із ХТВ (табл. 1). 
Критерії оцінки результатів лікування

\begin{tabular}{|l|c|c|c|}
\hline \multirow{2}{*}{ Критерії } & \multicolumn{2}{|c|}{ Результат } \\
\cline { 2 - 4 } & Добрий & Задовільний & Незадовільний \\
\hline Біль у спокої & Відсутній & Зменшився & Посилився \\
\hline $\begin{array}{l}\text { Набряк (більше для } \\
\text { венозних ХТВ) }\end{array}$ & Відсутній & Зменшився & Посилився \\
\hline $\begin{array}{l}\text { Трофічні зміни шкіри і } \\
\text { дериватів }\end{array}$ & Відсутні & Зменшилися & Посилилися \\
\hline $\begin{array}{l}\text { КПІ (для ішемічних } \\
\text { ХТВ) }\end{array}$ & $\begin{array}{c}\text { Зростання на 0,2 } \\
\text { і більше }\end{array}$ & 3ростання на 0,1-0,2 & Без змін або зменшення \\
\hline $\begin{array}{l}\text { Доплер-тиск на зад- } \\
\text { ньогомілковій артерії } \\
\text { (ішемічні ХТВ) }\end{array}$ & >70 мм рт. ст. & $50-70$ мм рт. ст. & <50 мм рт. ст. \\
\hline $\begin{array}{l}\text { Виразки або некрози } \\
\text { Висока ампутація (для }\end{array}$ & Загоєння
\end{tabular}

Тривалість лікування різних груп хворих показана на рисунку 2.

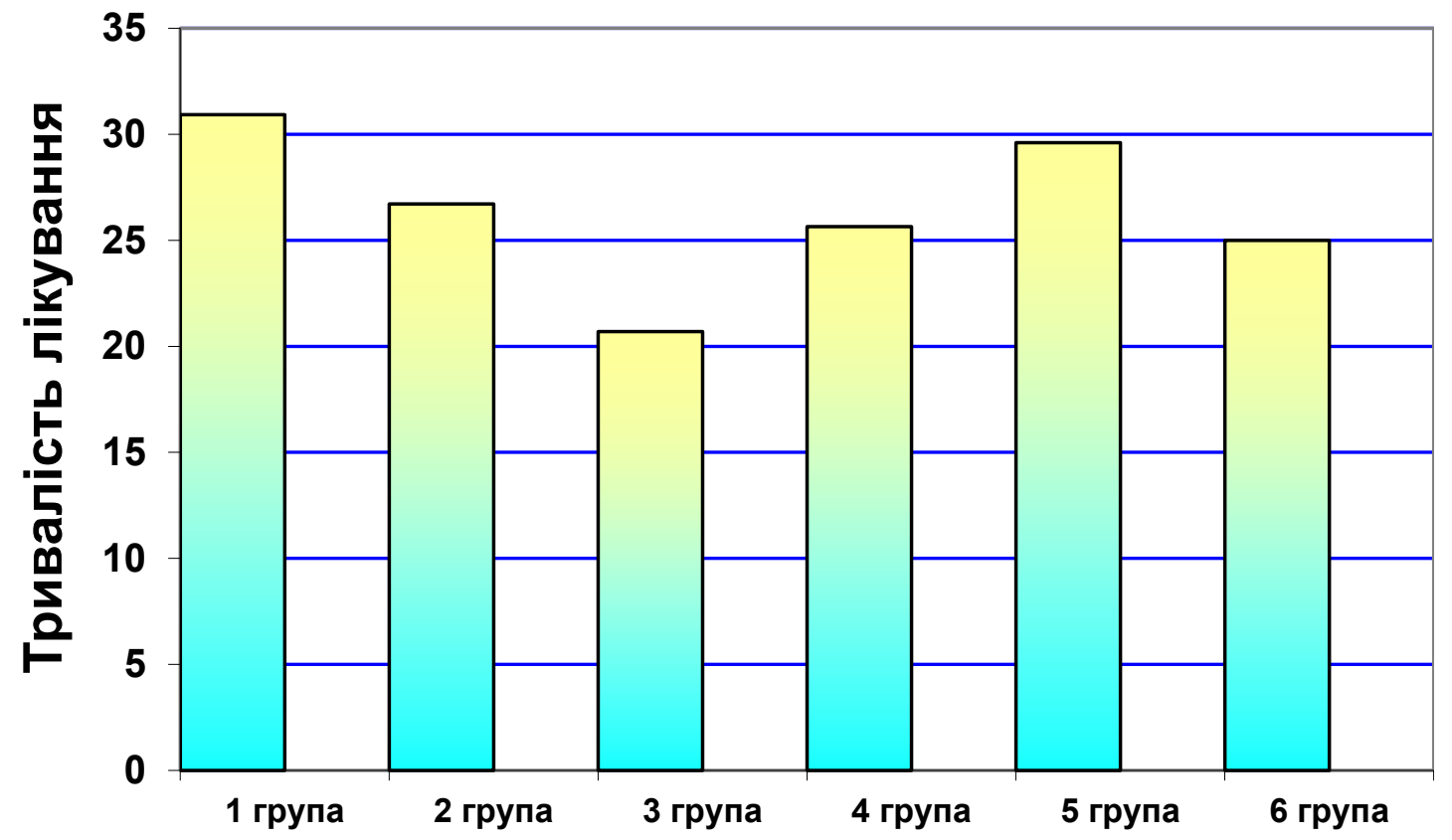

Рис. 2. Тривалість середніх термінів лікування різних груп хворих.

Безумовним критерієм вилікування даної патології у віддаленому періоді є відсутність рецидиву ТВ. Добрий результат - рецидив виразки відсутній, задовільний результат - наявність ХТВ нижньої кінцівки іншої локалізації (несправжній рецидив), незадовільний - рецидив виразки в первин- ній локалізації. Також безумовним критерієм для ішемічних ХТВ у віддаленому періоді є виконання високої ампутації.

Безпосередній і віддалені результати лікування груп хворих показані в таблиці 2. 
Результати лікування груп хворих

\begin{tabular}{|c|c|c|c|c|}
\hline \multicolumn{2}{|c|}{ Результати } & Добрий & Задовільний & Незадовільний \\
\hline \multirow{6}{*}{ Безпосередні } & перша & $11(40,7 \%)$ & $14(51,9 \%)$ & $2(7,4 \%)$ \\
\hline & друга & $4(26,7 \%)$ & $7(46,6 \%)$ & $4(26,7 \%)$ \\
\hline & третя & $15(75 \%)$ & $4(20 \%)$ & $1(5 \%)$ \\
\hline & четверта & $7(46,6 \%)$ & $5(33,4 \%)$ & $3(20 \%)$ \\
\hline & п’ята & $82(91,1 \%)$ & $8(8,9 \%)$ & - \\
\hline & шоста & $36(54,5 \%)$ & $25(37,9 \%)$ & $5(7,6 \%)$ \\
\hline \multirow{6}{*}{ Віддалені } & перша & $6(22,2 \%)$ & $7(25,9 \%)$ & $14(51,9 \%)$ \\
\hline & друга & $1(6,7 \%)$ & $4(26,7 \%)$ & $10(66,6 \%)$ \\
\hline & третя & $5(25 \%)$ & $8(40 \%)$ & $7(35 \%)$ \\
\hline & четверта & $2(13,3 \%)$ & $5(33,4 \%)$ & $8(53,3 \%)$ \\
\hline & п’ята & $65(72,2 \%)$ & $19(21,1 \%)$ & $6(6,6 \%)$ \\
\hline & шоста & $25(37,9 \%)$ & $26(39,4 \%)$ & $15(22,7 \%)$ \\
\hline
\end{tabular}

Із поданої таблиці видно, що віддалені результати першої і другої груп лікування найгірші. Консервативне лікування хронічної венозної недостатності, ускладненої трофічними виразками, дає тимчасовий ефект і повинно розглядатися, як підготовка до оперативного лікування. При ішемічних ХТВ використання фармакопрепаратів приносить тільки тимчасовий ефект, і в подальшому закінчується рецидивом ХТВ або високою ампутацією.

Використання ізольованої автодермопластики без оперативного покращення кровопостачання при венозних і ішемічних ХTВ дає дещо кращі тільки безпосередні результати. При венозних ХTВ не усувається патогенетична причина розвитку виразок.

Аналіз причин рецидивів у венозних прооперованих хворих 5 групи показав, що рецидивна ТВ утворилася в рубцевій тканині на місці самостійно загоєної ХТВ (у двох хворих) без використання автодермопластики, або на місці часткового чи повного відшарування (по одному хворому) шкірного клаптя після операції без використання висічення ТВ. Таким чином, найбільш несприятливим у відношенні появи рецидивної ТВ є рубцева тканина, що є показом до більш широкого використання автодермопластики.
При частковому або повному некрозі шкірного клаптя, при можливості, необхідна рання повторна автодермопластика.

У віддаленому періоді терміном спостереження до 5 років у шостій групі артеріальних хворих із КННА високу ампутацію виконано 15 хворим $(22,7 \%)$. У другій групі високу ампутацію виконано 10 хворим $(66,7 \% \%)$, в четвертій $-8(53,3 \%)$ хворих. Отже, вдалося досягти більш, ніж в 2 рази зменшення високих ампутацій у віддаленому періоді у хворих з ішемічними ХТВ.

Висновки. Досягти стійкого і позитивного результату можна тільки при використанні комплексного підходу до лікування. При венозних ХТВ обов'язкове використання нових методів консервативного лікування, АВПКШ із радикальною операцією на венозній системі.

Використання катетеризації нижньої надчеревної артерії, доартеріальної інфузії, остеоперфорації великогомілкової кістки покращує результати лікування хворих із КІНК.

Перспективні методи лікування. Місцево для лікування ХТВ використання спреїв із факторами росту фібробластів, фактором росту тромбоцитів або ендотеліальним фактором росту. При КІНК для стимуляції неоангіогенезу використання стовбурових і плацентарних клітин.

Інформація про конфлікт інтересів. Автори заявляють про відсутність конфлікту інтересів при виконанні наукового дослідження та підготовці даної статті. 
Інформація про фінансування. Автори гарантують, що вони не отримували жодних винагород у будь-якій формі, здатних вплинути на результати роботи.

Особистий внесок кожного автора у виконання роботи:

Пиптюк О.В. - розробка концепції і дизайну дослідження, аналіз отриманих даних, редагування, статистична обробка даних.

Телемуха С.Б. - збір матеріалу дослідження, розробка дизайну дослідження, аналіз отриманих даних.

Дуб O.I. - збір матеріалу дослідження, аналіз отриманих даних, підготовка тексту статті.

Телемуха Л.Б. - збір матеріалу дослідження, аналіз отриманих даних, підготовка тексту статті.

\section{Список використаної літератури}

1. Conte M. S., Bradbury A. W., Kolh P., White J. V, et al. Global vascular guidelines on the management of chronic limb-threatening ischemia. J. of Vascular Surgery. 2019; 6 (969): 125-36

2. Rowe V. L. Diabetic Ulcers Treatment \& Management. Updated: Mar 14. 2017; https://emedicine.medscape.com/article/460282-medication.

3. Diabetic foot problems: prevention and management.- NICE guideline. 2016; https://www.nice.org.uk/guidance/ng. 19.- 49.

4. Sopata M., Kucharzewski M., Tomaszewska E. Antiseptic with modern wound dressings in the treatment of venous leg ulcers: clinical and microbiological aspects. 2016;25(8):419-26.

5. Нікульніков П. І., Ліксунов О. В., Ратушнюк А. В., Бічер А. Г. Можливості лікування трофічних виразок у хворих із декомпенсованими формами хронічної венозної недостатності нижніх кінцівок із використанням спрею КадефортТМ. Здоров’я України «Хірургія, Ортопедія, Травматологія, Інтенсивна терапія» 2019; 1 (35):19-24

6. Hingorani A. The management of diabetic foot: a clinical practice guideline by the Society for Vascular Surgery in collaboration with the American Podiatric Medical Association and the Society for Vascular Medicine. J. Vasc. Surg. 2016; 63: 3-21.

7. Lipsky B. Infectious Diseases Society of America Clinical Practice Guideline for the Diagnosis and Treatment of Diabetic Foot Infectionsa. Cl.1 Inf. Dis.2012;54: 132-73,

8. Bronze M. Diabetic Foot Infections Treatment \& Management. 2017;5: https://emedicine.medscape.com/article/237378

9. Haycock S. Debridement of diabetic foot wounds. Nursing Standard; 2012; 26.51-8.

10. Kamaratos AV, Tzirogiannis KN, Iraklianou SA, Panoutsopoulos GI, Kanellos IE, Melidonis AI. Manuka honey-impregnated dressings in the treatment of neuropathic diabetic foot ulcers. Int Wound J 2014; 11: $259-63$. [RCT]

11. Dumville JC, O’Meara S, Deshpande S, Speak K. Hydrogel dressings for healing diabetic foot ulcers. Cochrane Database Syst Rev 2013; 7: CD009101.

Стаття надійшла до редакції: 14.01.2020 р. 